\title{
Deliberative democracy and the WTO Ilan Kapoor
}

Faculty of Environmental Studies, York University, Toronto

\begin{abstract}
Habermas's rules-based deliberative democratic perspective underscores issues of power, legitimacy and justice. The article deploys this perspective to reveal how the lack of legitimating procedures and rational deliberation at the World Trade Organization (WTO) yields power politics and unjust outcomes. It examines the rule-making process in the successive trade Rounds that led up to the WTO, as well as the politics of the organisation's rule-application and consensus-making practices.
\end{abstract}

\section{KEYWORDS}

Deliberative democracy: political legitimacy; WTO decision making; consensual international agreements; North-South trade negotiations.

\section{INTRODUCTION}

The World Trade Organization (WTO) has become a highly significant global body, acting as a permanent forum for liberalisation of trade in goods and services, and increasingly, for the management of global investment and intellectual property rights. It currently boasts a membership of 146 states, with some 30 'transition' and developing countries eagerly waiting to join. Together, its members engage in some 90 percent of world trade and investment. But its growing global power, especially in the wake of the Seattle debacle of 1999, have also engendered growing public scrutiny. Several analysts and critics (e.g. Bello, 2000; Conca, 2000; Keohane and Nye, 2000; Khor, 2000; McMichael, 2000) point out that, despite its outwardly democratic ways, it has questionable decision-making procedures that result in hegemonic western neoliberalism and/or a 'deficit' - if not a 'crisis' - of legitimacy and accountability.

In this article, I will side with these critics, but I will do so from a Habermasian standpoint. Perhaps more than any other democratic theorist, Habermas provides a way of systematically examining and assessing 
liberal democratic institutions. With the goal of extending and radicalising democracy, his 'deliberative democracy' is a rules-based deliberative process that underscores issues of legitimacy and justice. And although not itself beyond reproach (a point I will elaborate in the article), this deliberative process assists in evaluating decision making at the WTO, which is also rules based. Thus, deliberative democracy helps reveal how inadequate legitimating rules and lack of rational deliberation in the WTO yield power politics, coerced decision making and unjust outcomes.

After outlining Habermas's deliberative democratic vision, I will examine the rule-making process in the successive trade Rounds that led up to the WTO. I will then analyse the power politics involved in such rule making, and how this politics, coupled with the absence of qualitative deliberation among WTO members, have given way to dubious consensus and decision making, especially from the perspective of developing countries.

\section{DELIBERATIVE DEMOCRACY}

In Structural Transformation of the Public Sphere (1989), Jürgen Habermas argues for a 'public sphere' in which citizens deliberate dialogically. $\mathrm{He}$ distinguishes it from the state and economy, which he characterises as realms governed by power and money, respectively, and against which the public sphere must guard. In more recent writings (e.g. 1996a,b), he develops the specifically discursive elements of the public sphere under the rubric of 'deliberative democracy'. Here, he argues for politics as a type of conversation, grounded in legitimating rules and reasoned dialogue: 'democratic will-formation draws its legitimating force ... from the communicative presuppositions that allow the better arguments to come into play in various forms of deliberation and from the procedures that secure fair bargaining processes' (1996a: 24).

Habermas encapsulates these fair bargaining processes under what he calls an 'ideal speech situation' - a set of formal rules or conditions which he contends are inherent and anticipated in human communication (1990: 86-7). ${ }^{1}$ These rules ensure free and uncoerced conversation. Thus, an ideal speech situation prevails when it is: (1) inclusive, i.e. no one is excluded from articulating topics relevant to her/him, and no relevant information is left out; (2) coercion free, i.e. participants engage in arguments free of domination or intimidation; and (3) open and symmetrical, i.e. each participant can initiate, continue and question the discussion on any relevant topic, including the very procedures that govern the discussion (1990: 88-9, 197; 1976: 107-9; Benhabib, 1996: 70).

Habermas's proceduralist approach to democratic decision making means that no limits are imposed on the content or scope of the dialogue: the discussion agenda is left open, with the recognition that decisions taken 
are temporary and may need to be revised when information or circumstances change. However, his proceduralism does impose strict limits on the power relations between interlocutors. He writes, for example, about the need for a modicum of socioeconomic equality among participants so they can participate on a relatively equal footing (1993a: 68-9). However, he is aware that such conditions are difficult to realise in practice. And he is quick to point out that his ideal speech situation is not empirical or descriptive; it is a regulative notion, a counterfactual stance from which to criticise both power politics and those decision-making processes that arbitrarily constrict or impose political agendas.

As alluded to earlier, of particular concern to Habermas is domination by the market and the state, which, motivated by material and power concerns, tend to impose financial/fiscal and administrative/technocratic solutions (1976). For him, corporate and state interests can often coerce legitimacy and public consensus through domination, manipulation or commodification of culture. Such depoliticisation, such removal of critical discourse and limitation of social choices, yield what Habermas calls 'ideology' (1976: 80ff). The ideal speech situation is aimed precisely at minimising ideology and maximising decision making by civil society. Not surprisingly, of late he emphasizes the need to institutionalise through legal and constitutional means the formal conditions of the ideal speech situation so as to both reduce systematically distorted communication and better regulate, guarantee and expand the public sphere (1996b).

But it is not enough to have legitimating rules; bringing about just and democratic outcomes or decisions requires rational discourse. Here, Habermas has in mind, not an autonomous reason that calculates independent of society, but a 'communicative rationality' that acts in concert with others. Deliberative democracy is about a socially generated dialogue of reason, the to and fro of argument and counter-argument. Consensus is reached only through the (unforced) 'force of the better argument', that is, only when every participant accepts explanations and decisions as reasonable (1990: 88ff, 160, 198). Thus, consensus is produced through argumentation, not power politics or by the force of an interlocutor's privileged socioeconomic status. The overall goal is for the community or state to reflect this consensus in laws and policies.

The quality of consensus-making is imperative in order to arrive at just or fair outcomes. In this regard, Habermas argues against 'mere agreement' and 'bargaining' in favour of a 'rational consensus' (1990: 67, 198; 1976: $111 \mathrm{ff}$ ). 'Mere agreement' is a consensus reached by aggregating individual interests or adding up votes. This ballot-box type of decision making is polarising, producing all-or-nothing outcomes (depending on whether one belongs to the winning majority or the losing minority) and the rule or even the tyranny of the majority. 'Bargaining' involves mutual trading of benefits and costs and often encourages the use or acquisition of influence 
and power by buying or selling votes. It means making compromises and, frequently, catering to the lowest common denominator, thus lowering the quality of the democratic consensus. ${ }^{2}$ In contrast, 'rational consensus' is reached through a 'higher-level intersubjectivity of communication processes' (1996a: 28). In this case, every participant enters the public space with her/his individual preferences, and through reasoned debate, arrives at an expanded view that seeks the good of all. The debate includes the airing of views, the critiquing of those that are unfounded or unconvincing, and adjudication between weaker and better claims. The construction of an enlarged standpoint, for its part, usually involves self-critique, by bringing in 'universal principles of justice into the horizon of the specific form of life of a particular community' (1996a: 25). Thus, the quality and justice of the consensus is ensured by rational and critical argumentation that seeks the generalisability or universalisation of interests.

Before assessing WTO decision making in light of the above, it is important to reflect on the extent to which the deliberative democratic perspective is applicable to the WTO. For, it may be objected, Habermas has in mind a territorially bound space (i.e. the nation-state) and a historically specific place (i.e. liberal democracy as it has developed in the West) when speaking about deliberative democracy. Moreover, the WTO is a state-centred and trade-related institution, which hardly qualifies it as a public sphere distinct from state or economy. Although both objections appear to have merit, I do not believe them to hold much weight. It is true that Habermas's early writing (e.g. 1989, first published in 1962) analyzes the historical rise of the public sphere in Europe; however, the bulk of his political project since then has been about the transhistorical and universal human capacity for communicative rationality. As several analysts have argued (e.g. Bernstein, 1993; Calhoun, 1992: 31-2, 40; White, 1984: 32), deliberative democracy is precisely about finding a 'transcendental basis for democracy' (Calhoun, 1992: 32). Besides, a public space is not necessarily place- or space-bound; it occurs anytime and anywhere political actors cohere and engage in debate (as indeed states do through their representatives at the WTO). In this connection, Hannah Arendt, another theorist of the public sphere, writes that the 'polis, properly speaking, is not the city-state in its physical location; it is the organisation of the people as it arises out of acting and speaking together... no matter where they happen to be... "Wherever you go, you will be a polis"' (1958: 198). And to wit, the post/transnationalisation of the public sphere has become a preoccupation of Habermas himself in his recent writing (cf. 1999, 2001), indicative of the importance he attaches to extending and radicalising democracy beyond local or national boundaries.

As to the second objection, the WTO is neither state nor market; it is a multilateral forum for negotiation. True, it has a secretariat, but this is a relatively small bureaucracy that administers decisions issuing from collective 
negotiations. True as well that it deals with economic matters. But the WTO is not itself a market; it is a place to discuss rules about the global market, in the same way that a nationally based public sphere may debate regulations governing the national economy. Thus, the WTO eminently qualifies as a public space, in this case a multilateral sphere. Within it, national representatives deliberate (i.e. they make, defend and adjudicate claims), primarily about global economic matters. But although the WTO may be a multilateral (and purportedly a democratic) sphere, to what extent this sphere is legitimate and rationally deliberative remains to be seen.

\section{MULTILATERAL TRADE RULE-MAKING}

Habermas closely ties means to ends, so that, as noted earlier, it is the process of decision making that gives decisions their 'legitimating force'. Accordingly, one needs to examine the process (and history) of international trade rule making in order to assess the trade rules. Of course, space considerations do not allow me to analyze this process in any detail; I shall investigate merely its broad outlines.

The WTO's claim to being a democratic organisation is based on the fact that there is sovereign equality (i.e. it has a one-country, one-vote decisionmaking system). However, since the late 1950s, virtually all decisions have been taken by consensus (Steinberg, 2002: 344). During most of the period covering the General Agreement on Tariffs and Trade (GATT, 1948-1994), consensus making was common practice; but since the creation of the WTO in 1995, this practice has been formalised. Article IX of the Marrakesh Agreement Establishing the WTO stipulates that all decisions are to be taken by consensus, which is to say that unless a member present formally objects to a proposed measure, it carries. If and when a consensus cannot be reached, a decision is taken by a majority vote (of two-thirds or threefourths, depending on the nature of the decision) (WTO, 1994). Each WTO member has the right to attend meetings, make or withdraw proposals or legal briefs, suggest amendments, and approve or oppose the consensus. Thus, the principle of sovereign equality applies, but within a mainly consensus-making system.

The WTO includes 23 separate agreements, most of which were negotiated under several GATT Rounds that took place before 1995: the Dillon Round (1960-1961, devoted mainly to tariff reductions), the Kennedy Round (1964-1967, mainly tariffs and anti-dumping), the Tokyo Round (1973-1979, mainly tariffs and non-tariff barriers) and the Uruguay Round (1986-1994). The Uruguay Round ended in the establishment of the WTO, but it deviated considerably from the other Rounds by including measures, not just to further trade liberalisation (through tariff reductions, particularly in agriculture, textiles and footwear, as well as the continued elimination of non-tariff barriers), but also to cover new areas such 
as investment (under TRIMS, the Trade-Related Investment Measures). services (under GATS, the General Agreement on Trade in Services) and intellectual property (under TRIPs, the Trade-Related Aspects of Intellectual Property Rights). In 2001, within the ambit now of the WTO, members reached agreement to begin another 'work program' (which is indistinguishable from a Round). The Doha Work Program (2002-2005, sometimes called the Millennium Round) aims at continuing negotiations on agriculture, anti-dumping and investment, adding a new area (competition policy), and for the first time, beginning to look at the environmental dimensions of trade.

Deliberations in each Round happen in various specialised working groups and drafting committees (small and large), with proposals working their way through various WTO/GATT council and ministerial meetings. Of note are the Ministerial Meetings, which are the penultimate decisionmaking body and usually happen when there is sufficient momentum on a number of fronts to warrant a high-level, ministerial meeting, typically every 2 years (Shrybman, 2001: 2). Each Round involves three distinct phases: a launch phase in which members agree to a new Round and its main agenda items; the negotiation phase, in which the hard deliberations take place; and the concluding phase in which the final (usually high-level) talks happen and the agreements are signed.

For the most part, the Round launch phase has been the least controversial, with a reasonably good quality of consensus making (Steinberg, 2002: 350-1). Some exceptions exist, notably at the 1999 Seattle Ministerial Meeting, which was scuttled in part when several developing-country delegates were not invited to meetings of direct interest to them (Sampson, 2000: 1101). But generally, consensus has been easier to reach in this phase because most of the issues members have wanted to be part of the Round have been accommodated into the agenda. For example, Argentina, Brazil, Egypt, India and Yugoslavia opposed the launching of the Uruguay Round until several topics, including liberalisation of trade in tropical products and textiles, were put on the table (Steinberg. 2002: 352). Similarly, in the lead-up to the Millennium Round, western countries wished to put new areas on the agenda (labour standards, competition policy, measures to protect the environment), while developing countries opposed them, arguing instead for the continued implementation of the Uruguay Round (in such areas as TRIPS, and with the support of the US and Canada, the continued liberalisation of the EU agricultural sector); a consensus was reached by including on the agenda most of the topics from both camps.

Deliberations have been much messier in the negotiation and concluding phases. There is now quite a bit of evidence to suggest that these talks have happened mainly along North-South lines, with the northern countries squarely in the driving seat. As Richard Steinberg writes, the 'EC and United States have dominated advancing initiatives at the GATT WTO for 
at least 40 years' (2002: 355; cf. Rugman, 2001: 6). The structural reasons for this trend will be analyzed in the next two sections. For the moment, it is important to note the ostensible reason: most of the key deliberations have happened in restricted, 'green room' meetings or caucuses. These have usually taken place first in Brussels and Washington among the socalled Quad members (the EU, US, Japan and Canada), and then in larger groups made up of 20-30 western members. More often that not, the draft outputs from these caucuses have been presented and adopted at the formal WTO/GATT plenary sessions, where they have tended to be accepted without amendments (Bello, 2000: 86; Khor, 2000: 14-15; Kwa 2002: 15ff; 42-3; Raghavan, 2000: 497; Steinberg, 2002: 355). Gary Sampson notes that several developing countries, especially smaller ones, are 'systematically absent from not only informal, but also formal meetings' (2000: 1100); and when they are present and make proposals, it is not uncommon for these to be blocked, ignored or excluded (Khor, 2000: 16; Kwa, 2002: 13; Steinberg, 2002: 355).

Probably the most vivid illustration of western clout is to be seen in the actions of the US at the conclusion of the Uruguay Round. Faced with developing-country reluctance to accept agreements covering intellectual property rights, investment and services, the US threatened to withdraw from the Round and cancel its obligations to any member refusing to sign the Final Act (Steinberg, 2002: 360; see also McMichael, 2000: 469). With the backing of the EU, it succeeded in presenting a 'single undertaking' not only to close the Round, but also create a new regime under the WTO. As Steinberg points out, the US is probably the only country that could have successfully carried out its threat; it thus chose 'to coerce by exiting GATT and reconstituting the system [by creating the WTO]' (2002: 357). In addition to heeding the US threats, the developing countries were convinced to sign on when they were granted tariff reductions on footwear and textiles by the West (although these have been 'end-loaded', that is, they are to take effect only in 2005, at the end of the applicable 10-year period) and an 11-year transition period (ending in 2006) for implementing TRIPS.

A notable feature of the Uruguay Round agreements was the creation of a Dispute Settlement Body (DSB) under the WTO banner. The DSB's rulings (exercised by a three-member panel) are legally binding, that is, national laws that do not conform to WTO agreements or rulings must be modified, and in the case of continued non-compliance, the aggrieved party is entitled to compensation and retaliatory measures. To date, some 300 disputes have been raised with the DSB, which is many more than during the nearly 50 years of GATT (Bronckers, 2001: 45). In fact, the advent of the DSB is a significant change from GATT. As Dymond and Hart contend, the 'WTO shifted the centre of gravity of international trade rules from negative prescription to positive rule-making' (2000: 22). In contrast, under 
GATT, disputes were settled (and in fact avoided) by means of diplomatic talks between the parties, followed by a consensual agreement among all members, including the grieving parties.

\section{LEGITIMATING PROCEDURES?}

As the previous section implies, and this section will explicate, missing at the WTO/GATT are meaningful rules/procedures and conditions - suggested by Habermas's ideal speech situation - that would legitimate its democratic decision-making process. There appears to have been a semblance of law-based negotiating in the launch phases of the trade Rounds, but domination and coercion by the powerful western states for most of the rest of the process (Steinberg, 2002: 354, 365).

The exclusionary dimensions and exclusivity of the western-organised 'green room' caucuses are the most obvious sign of illegitimacy. Markus Krajewski notes that 'the green room process is clearly an element of a power-oriented and not of a rules- or principles-oriented system' (2001: 169-70; cf. Khor, 2000: 14-15). It may well be unrealistic and impractical to expect all countries to be represented at all caucus meetings. Moreover, southern countries do organise their own informal caucuses (Sampson, 2000: 1100). However, it is the repeated and systematic exclusion or neglect of many developing countries in key caucus meetings that is troubling. The main problem is that there are no clear and transparent (and dialogically generated) rules regulating such caucuses, ensuring for instance that all members are at least invited to them, or if not, spelling out the criteria for inclusion and exclusion. The absence of such rules means that the most powerful western members can continue their strong-arm tactics with impunity.

An important structural issue, putting many developing countries at a disadvantage, is their lack of resources, capacity and/or expertise for effective deliberation. Sampson writes that 'most small delegations do not have the appropriate resources either in Geneva or in their capitals to service the negotiating process and thereby participate meaningfully in what could be meetings of primary importance for their national interests' (Sampson, 2000: 1100). Half of all sub-Saharan African countries (15 of a group of 30 countries) do not even have a delegate resident in Geneva, this compared to an average of five delegates per mission, and a higher number for many developed countries (Blackhurst et al., 2000: 498-9). Several of those developing-country members that do have a Geneva presence report participating in meetings with few negotiating briefs and little access to technical or legal analysis (Blackhurst et al., 2000: 494; Chadha et al., 2000: 433; Kwa, 2002: 44).

Leading western-country members have made several offers of technical assistance to disadvantaged WTO members, but little has actually been 
forthcoming. The WTO's budget for this purpose is small, amounting to some $\$ 7,000$ annually per developing-country member (Blackhurst et al., 2000: 505ff.; Chadha et al., 2000: 434; Sampson, 2000: 1100). As part of its post-Seattle efforts to increase public transparency and accountability, the secretariat has made more documents and analysis available online, including its newsletter, WTO Focus (cf. Moore, 2002; WTO, 2000). But to what extent this move is a blessing or a curse for developing countries is unclear, since internet access tends to be restricted to higher-income, urban and mostly developed-country audiences, and those developingcountry delegations without access will no more receive the printed newsletters upon which they have hitherto been relying (Wilkinson, 2002: 132).

Developing countries have themselves tried to strengthen their deliberative positions. By all accounts, Seattle and Doha showed a more active southern participation than ever before, with southern members authoring almost half of the submissions for the Ministerial Declaration that ensued (Chadha et al., 2000: 432). The establishment of the G-22 group of developing countries at the 2003 Cancun Ministerial Meeting, which opposed the US and EU-led agricultural proposals, is also a positive development. ${ }^{3}$ But as we have just seen, overall, there are significant structural inequalities that result in asymmetrical deliberative capacities, to the detriment of the South. These inequalities explain why many developing countries are not present or ill-prepared at some meetings (as alluded to earlier); and why several delegates report being overwhelmed and intimidated during deliberations (Blackhurst et al., 2000: 494, 499ff.; Kwa, 2002: 53-4). By the same token, these inequalities suggest why developed countries tend to be better informed and placed to negotiate, and why they can (and do) exclude, ignore or coerce their peers during deliberations.

Just as there is a politics of inclusion and exclusion that goes on within the WTO's multilateral sphere, there is one that goes on outside it. Multinational corporations (MNCs) have had a significant presence in, so to speak, the 'shadows' of WTO deliberations. Scholte et al. report that 'In a rough ranking, conformers like business associations [as opposed to nonconformers like many environmental NGOs] have usually had easiest access. Thus, for example, 65 percent of the civic organisations accredited to attend the Singapore Ministerial Conference represented business interests' (2001: 118). MNCs not only send their representatives to WTO gatherings, ${ }^{4}$ they also lobby national delegations. Thus, Smith and Moran write that 'More than five hundred corporation and business representatives were given official credentials as "trade advisors" to the US delegation in Seattle' (1999; 68; cf. Madeley, 2000: 63; McMichael, 2000: 466; Williams, 2001: 45-6, 52). The reason for such a strong presence is that MNCs have much to gain or lose from WTO negotiations: in 1999, they accounted for a third of all global exports, with a handful of them virtually controlling 
such global sectors as telecommunications, pesticides, commercial seed and computing (McMichael, 2000: 468; Raghavan, 2000: 497; Shrybman, 2001: 3). They also have much to gain or lose from WTO/DSB rulings, as illustrated for example by the recent EU-US disputes over bananas and the foreign sales corporation tax. ${ }^{5}$

In contrast, NGOs, especially critical ones (as intimated by Scholte et al. above), have had a more difficult time accessing the WTO. Although several have successfully publicised this inaccessibility, they have also encountered notable resistance. To wit: NGOs are allowed to attend WTO Ministerial Meetings, and many do - some 650 were present at Doha, for example; but their access is restricted and controlled. WTO guidelines limit their attendance to only some meetings and symposia, make only 'informal arrangements' for receipt of NGO briefs and papers, and allow chairs of WTO councils or committees to meet with them only 'in their personal capacity'. The guidelines conclude that, overall, 'it would not be possible for NGOs to be directly involved in the work of the WTO or its meetings' (WTO, 1996; cf. Moore, 2002). Of late, the secretariat has agreed to carry out more briefings, seminars and 'dialogues' with NGOs, but these are unofficial and take place mostly in Geneva.

The resistance to a more significant NGO presence appears to be based on the argument that they are unelected and hence illegitimate. For example, in an interview with the Financial Times during the Seattle stand-off, Mike Moore, the outgoing WTO director-general, asks how NGOs, who 'never [get] a vote and [don't] actually do anything can come out and attack [the WTO for being undemocratic]?' (quoted in Smith and Moran, 1999: 68). The problem with this line of thinking is that it exclusivises the nationstate and territorially-rooted electoral politics as politically legitimate. It ignores that many civil society movements and organisations have arisen out of state exclusion and oppression or the failure of electoral politics to adequately represent their issues (Esty, 1998; Held, 1995: 267). As a result, NGOs may be said to have a functional, not electoral or territorial, representational importance. They politicise issues (environment, human rights, small farming, child labour, etc.) that have been systematically neglected by nation-states or are absent from national agendas at the WTO precisely because they are extra-national (i.e. global). NGOs can therefore be seen as an alternative and complementary form of democratic governance and representation, acting as a counter-balance to state representation in global or multilateral spheres (Esty, 1998: 135-37). In the WTO's case, NGOs can also be seen as acting as a counter-weight to the MNC's significant influence.

This is not to say that NGO access to the WTO should not be subject to limitations, for example requiring them to go through accreditation procedures. However, even with an expanded role, there are many pitfalls deciding which ones are to be included and excluded and according to 
what criteria, correcting for those that get better or worse and more or less access, etc. For example, as Rorden Wilkinson argues, 'the WTO's emerging regime for dealing with NGOs is likely to continue to favour those well organised, Northern-based NGOs that can demonstrate a legitimate interest in WTO affairs and which pursue a largely unthreatening agenda precisely those NGOs that already have access to the WTO' (2002: 134; cf. Barfield, 2001: 107; Shaffer, 2001: 99). For this reason, developing countries tend to be suspicious of the inclusion of NGOs in the WTO negotiating process.

This is not to say, as well, that states must not uphold democratic processes, and as the WTO itself puts it, bear 'responsibility for taking into account the different elements of public interest which are brought to bear on trade policy-making' (WTO, 1996; cf. Raustiala, 1996: 7; Shaffer, 2001). There is a 'legitimacy chain' that moves all the way down from the WTO national representative to the citizen and local community. The links in this chain, however, are often broken or inadequate. Depending on issues and delegations, some national representatives and negotiators at the WTO are liable to be more accountable to balancing diverse national interests (citizens, communities, NGOs, labour, private sector, scientists, etc.), while others are not. These representatives are usually appointed diplomats and bureaucrats, although at times they are elected government ministers (Krajewski, 2001: 175). After they negotiate and sign WTO agreements, they present them to parliament for consent. However, with the exception of the more rigorous US congressional review process, ${ }^{6}$ to date most parliamentary oversight of these agreements has tended to amount to a rubber-stamping exercise, many parliamentarians investing little time and discussion (Barfield, 2001: 17ff.; Bellmann and Gerster, 1996). Given these often weak and arbitrary legitimacy links, therefore, it is difficult to defend the notion that sovereign states by themselves can or do adequately defend or represent local, national or global interests at the WTO. As Krajewski writes, 'the longer the [legitimacy] chain becomes, the more transparent it has to be. If the length of the chain is combined with intransparency, it no longer supplies a sufficient degree of democratic legitimacy' (Krajewski, 2001: 176).

To conclude this section, let me briefly recapitulate the far from 'ideal speech situation' that reigns at the WTO. Despite an outwardly democratic process upholding sovereign equality, the organisation lacks legitimating procedures or rules to minimise power inequalities and curb power politics. In fact, its very privileging of national sovereignty tends towards exclusion. Its inadequate decision-making procedures end up providing a marked advantage to the deliberative position and capacity of some - the developed countries (especially the most powerful among them) and MNCs; and a disadvantage to others - the developing countries 
(particularly smaller or weaker ones) and NGOs (particularly nonconforming and southern ones). The result is a coercive and exclusive del iberative sphere, which as the next section will argue, produces questionable consensus and decisions.

\section{RATIONAL DELIBERATIONS AND JUST OUTCOMES?}

The lack of legitimating procedures at the WTO is complemented by a less than rational decision-making environment, as borne out by the poor quality of deliberations, on the one hand, and of knowledge, on the other. As to the first of these, the WTO's multilateral sphere involves less deliberation and more compromises and trade-offs, resulting in what Habermas calls a 'bargaining' consensus. 'The WTO decision-making process', writes Krajewski, 'is dominated by bargaining instead of arguing. Negotiators do not reach solutions and compromises by trying to convince each other on what is the best solution by rational arguments' (2001: 177; cf. Kwa 2002: $x$ ).

Part of the reason that deliberations tend towards bargaining is that, on the whole, the West has much greater trading and economic leverage than the rest of the world. The large internal markets and trading capacities of the US and EU, in particular, make it possible for them to engage in arm-twisting. For, their economic power (together they account for about 40 percent of world imports) allows them to absorb costs or potential threats; while small or weaker countries have much to lose from trade restrictions and much to gain from access to US/EU markets (Sampson, 2000: 1100; Steinberg, 2002: 347-8). Western countries also have at their disposal such 'carrots' as increased foreign aid or debt rescheduling to buttress their bargaining arsenals, which they often use to win over developing countries (Kwa, 2002: 58, 66). Indeed, as was outlined earlier, the conclusion of the Uruguay Round, in particular, was characterised by horse-trading, arm-twisting and 'package deals'. It is not, then, the 'better' arguments that triumph in this multilateral sphere, but the economically powerful, threatening and/or beneficial ones.

As to the quality of knowledge, the reason why Habermas emphasizes a non-coercive and inclusive public sphere is to maximise the opportunity that all relevant information, and the best arguments, will be aired and adjudicated. However, the presence of coercion and exclusivity at the WTO selis knowledge short. The relative depoliticisation of the multilateral sphere means that it is that information and those arguments that most benefit the western countries and MNCs - economic and technological information and arguments - that tend to prevail. The claim that free trade, liberalised markets and technology is beneficial to all WTO members may be convincing, but given that the prevailing power relationships are tipped 
precisely in favour of those who stand to (and do) benefit most from this claim, the conviction appears to be little more than what Habermas calls 'ideology' (i.e. the suppression of generalisable social interests through systematically distorted communication). The prevalence of neoliberalism at the WTO or elsewhere serves well, for instance, the primarily western MNCs wanting to enlarge their global markets in such areas as technology, culture, or health and drugs.

If economic and technological arguments are mostly in, then social or environmental ones are mostly out. This exclusion is related in part to the relative lack of access to the WTO by NGOs, many of which represent socio-environmental interests, including communities that are negatively affected by trade and economic liberalisation or privatisation. They are critical of not only their restricted access to WTO meetings, but also the absence of public scrutiny of the DSB. To be sure, the DSB hearings are carried out in camera, are open only to the grieving parties (not even to other WTO members), and do not entertain NGO submissions. Moreover, DSB panellists are mostly trade experts, economists and corporate lawyers, with little or no knowledge of non-trade issues (Barfield, 2001: 5; Conca, 2000: 485). The NGOs are thus correct in claiming that non-economic and non-technocratic arguments (such as environmental, labour or consumer oriented ones) are unlikely to be seriously entertained at the WTO. In fact, to date, DSB decisions have been pro-trade liberalisation and antienvironmental almost without exception (Conca, 2000: 486, Esty, 2000). This in spite of principles and clauses in WTO agreements ${ }^{7}$ that could be interpreted as pro-environmental.

The point that economic and technological claims prevail over others is not meant to convey that the WTO is a monolithic bastion of neoliberalism and westernisation. It does, after all, have a multilateral sphere, where dissenting views and non-economic and anti-westernisation arguments are held and sometimes aired by national delegates, even in the absence of critical NGOs. The point is that power fixes or privileges certain types of knowledge, and ignores and suppresses others, so that it is the knowledge claims of the dominant participants that tend to get naturalised. Thus, for example, several developing countries stand against the inclusion of issues such as the environment and labour on the WTO agenda (Bronckers, 2001: 46): they do so not necessarily because they are against environmental or labour rights, but because they suspect that the dominant WTO knowledge/power regime is likely to use environmental and labour standards to discriminate against them in precisely those areas in which they have a comparative advantage (i.e. the fact that they have low environmental and labour costs, which makes their exports cheaper, could be used against them).

The combination of inadequate legitimating procedures and lack of qualitative deliberations makes it unlikely that WTO outcomes will be just. In 
the midst of power politics, exclusion, bargaining and uncritical knowledge, the consensus reached in this multilateral sphere is most likely to be coerced and one-sided - to the advantage of western members. Of course, this imbalance may not always happen along western/non-western lines: there may be occasional losers within the West, for example as a result of the continuing US-EU dispute over agriculture (although even here, until the dispute is settled, it is developing-country farmers who end up bearing most of the brunt, from being shut out of western markets); and there will be exceptions, such as for instance the decision at Doha by the US to finally relent on allowing developing-country generic drug production in the case of epidemics such as HIV/AIDS. Overall, however, the WTO regime will tend (and has tended) to be advantageous to the West.

Levelling the playing field in trade and other global economic realms may well be the function of the WTO, but under conditions of coerced decision making and (historically and structurally) unequal trading relationships, levelling the playing field amounts to westernisation. An illustration of this is to be seen in the TRIPs and TRIMs agreements, which read as though developing countries can pay for and have easy access to technology and investment, and as though developed countries do not already dominate the global market in these areas (Bello, 2000: 76). The universal harmonisation envisaged in TRIPs and TRIMs thus translates into the rest of the world conforming to western patent/copyright and investment regimes. True, developing countries have been granted transition periods to implement these agreements; but Walden Bello is quick to point out that 'Although the GATT-WTO Accord does recognize the "special and differential status" of the developing countries, it does not see this as a case of structurally determined differences but as one of gaps that can be surmounted by giving developing countries a longer adjustment period than the developed countries' (2000: 74).

A last related point: under these unequal conditions, the DSB suffers multiple legitimacy problems. For, not only does it base its judgments on agreements resulting from questionable international consensus, but its deliberations are closed and its rulings binding. Whereas, as mentioned earlier, GATT rulings on disputes were imposed only with collective consent, WTO/DSB rulings have been judicialised; and judicialisation, Diamond and Hart contend, 'has taken rule-making out of the hands of members and made it appear distant and unaccountable' (2000: 25; cf. 34; Clarkson, 1999; Keohane and Nye, 2000: 33; Krajewski, 2001: 171). Now from the perspective of developing countries, DSB adjudication could be an insurance against the unilateralism of the powerful western states. However, given the power/knowledge inequalities mentioned earlier, this is not likely to be the case. Furthermore, judicialisation reproduces earlier resource inequalities, giving states with good legal resources an advantage 
and thus substituting western negotiating power with western legal power (Barfield, 2001: 75; Gabilondo, 2001).

\section{CONCLUSION}

To conclude, I want to reflect on the significance and relevance of Habermas's perspective in assessing decision making at the WTO. Deliberative democracy is important in helping understand the links between deliberation and issues of power, legitimacy and justice, so that when Mike Moore (or his successor) defends his organisation as democratic and contends that the 'WTO is not imposed on countries... No country is forced to sign our agreements' (quoted in Kwa, 2002: 14), his claims do not stand up well to scrutiny. For a start, it is improbable that in today's globalised economy, any country enjoys the choice of staying out of the WTO, no matter whether it perceives the WTO as democratic or not. Few countries and certainly no small country - can risk being isolated from the organisation's powerful and growing economic and trade ambit. Moreover, when a country does join, there are not many (legitimating) procedures to minimise power politics, exclusion and arm-twisting, with the result that it may indeed be forced to sign on to WTO agreements. Consequently, it may well find that the WTO has created the illusion of fair rules (democracy) and outcomes (trade or market liberalisation), from which powerful (and mainly western) states derive substantial advantage.

Given this bleak assessment of democratic politics at the WTO though, it seems justified to ask whether my Habermasian position sets too high a standard. In other words, is the gap between the ethical norm and the empirical case too wide? This would be a 'realist' counter-position, based on the view that international relations are too anarchic and replete with power to argue for transnational democratic legitimacy. I beg to differ on two grounds. First, I disagree fundamentally with the realist assumption of being able to take an impartial and descriptive stand on international relations, thus keeping at bay issues of legitimacy and morality. If the twentieth-century 'linguistic turn' in science and social science has taught us anything, it is that a description is always already a position. The politico-moral stand implied by realism appears to be the justification of 'what is', which translates into the continued use of coercion and power politics. Habermas's perspective is important because it upholds the need for an ideal from which to assess and criticise coercion, illegitimacy and injustice, whether at the WTO or other national and transnational institutions. Second, it is not as though deliberative democracy imposes ex nihilo the question of political legitimacy on the WTO. The WTO has itself instituted a multilateral sphere which it touts as democratic and consensual. The Habermasian perspective, like that of (at least a few of) the Seattle demonstrators, is aimed at assessing and criticising the legitimacy 
of this sphere, with a view to extending and deepening its democratic dimensions. As Thomas Risse puts it, there is a 'process of argumentative "self-entrapment" [in international organisations such as the WTO] that starts as rhetorical action and strategic adaptation to external pressures' and, with sustained public outcry and scrutiny, may end up 'with argumentative behaviour resembling the criteria defined [by deliberative democracy]' (2000: 32).

The types of measures that the WTO would have to take in order to close the wide gap between its democratic pretensions and practices are implicit in my above Habermasian critique. There is a dire need for collectively elaborated procedures to minimise power inequalities and maximise information/knowledge. Missing, in particular, are: (1) clear and transparent rules governing the 'green room' caucuses in order to broaden their membership, check against coercive negotiating tactics by powerful trading members, and guarantee a more equal geographic representation (cf. Schott and Watal, 2000); (2) the provision of significantly greater resources to small and economically weak developing-country members to help them improve their deliberative and legal capacities; and (3) the limitation or regulation of MNC involvement in national delegations and WTO deliberations. There is also a dire need for the WTO to re-consider making national sovereignty the sole basis of membership and representation. As we have noted, this policy results in closed-door trade discussions and DSB hearings. Inclusion of, and outreach to, a wide range of civil society organisations will better ensure qualitative deliberations and the incorporation of non-territorial and transnational issues and interests (e.g. environmental issues, human rights). In this regard, the WTO can take inspiration from other multilateral forums such as the European Economic and Social Committee (ESC), which carries out advisory/policy activities for the European Commission and parliament. The ESC successfully combines functional representation (of socio-economic NGOs) with territorial representation (of sovereign European members) (cf. Smismans, 2000).

But this is not to argue that the Habermasian perspective is without reproach: the WTO case does cast some doubt, in particular, on a consensusbased democratic system. Several critics $^{8}$ have warned that the risk of seeking a universal consensus is the suppression of difference (Benhabib, 1996: 7-9, 73ff.; Fraser, 1989, 1992; Young, 1996). This eventuality is borne out at the WTO, with smaller and weaker members' voices being ignored or denied by powerful ones. Of course, Habermas would respond by arguing, rightly, that difference is only denied because the conditions for a qualitative consensus do not exist at the WTO. The problem, however, may also be the very requirement of reaching a single and often once-and-for-all agreement. Habermas's critics have suggested the alternative of 'subaltern counterpublics' (Fraser, 1992: 123-4) and 'deliberative enclaves of resistance in which those who lose in each coercive move can rework their ideas and 
strategies, gathering forces and deciding in a more protected space in what way or whether to continue the battle' (Mansbridge, 1996: 47). The implications of this suggestion are left unclear, but presumably it would involve an agreement to disagree when there are irreconcilable differences, and the creation of multiple public spaces and multiple consensus. The practicability and feasibility of this suggestion may be doubtful, but at the very least it does point up the problematic power relationships inherent in the very search for (let alone the making of) a universal consensus at such global organisations as the WTO.

\section{ACKNOWLEDGEMENTS}

My thanks to the anonymous reviewers for their comments; and to Kent Murnaghan, as always.

\section{NOTES}

1 Note that, of late, Habermas appears to prefer the terms 'norms of discourse' and 'procedures of discourse' over 'ideal speech situation'.

2 More recently, Habermas recognizes that compromises may be necessary in exceptional circumstances - specifically conflicts over distributive issues, where participants are often highly polarised and consensus is almost impossible to reach (1993b: 448)

3 At the time of writing this article, it is too early to tell whether the formation and oppositional stance of the G-22 group (led by China, Brazil, India and South Africa) is a trend or an exception in WTO negotiations. The accession of China to the WTO may have emboldened and strengthened the negotiating position of these economically powerful developing countries. However, it is unclear how unified this group will remain or what the future US and EU reaction to such opposition will be. The US has already threatened that continued developingcountry opposition may cause it to seek out bilateral and regional, as opposed to multilateral, agricultural agreements.

4 MNC lobbying activities at WTO meetings include being able to act as 'host'. For example, Microsoft and Boeing co-chaired the 'Seattle Host Committee' at a cost of half a million dollars (Times of India, 1999).

5 The US-EU banana dispute is an overt case of opening the EU market to US fruit MNCs (i.e. the Latin American-based US companies, Chiquita - formerly the United Fruit Company - and Dole) at the expense of smaller Caribbean producers (Rugman, 2001: 9-10). The WTO ruled that the EU was discriminating against these MNCs (because the EU was honoring its Lome Convention obligations favouring imports from its ex-Caribbean colonies). The US-EU 'foreign sales corporation tax' dispute concerns the US government exempting from income taxes the offshore subsidiaries of US corporations such as Boeing, General Motors, Eastman Kodak, Microsoft and Caterpillar, which are located in tax havens and carry out export transactions on behalf of their parent companies (Rugman, 2001: 12-13). In 2002, the WTO found in favour of the EU.

6 Of late, this review process seems to be eroding: in late 2002, the US Congress gave George W. Bush fast-track 'trade promotion authority' to negotiate trade agreements, that Congress will vote on (on a 'yes' or 'no' basis), but will no more have the option of amending. 
7 For example, the preamble of the WTO agreements call for 'expanding the production of and trade in goods and services, while allowing for the optimal use of the world's resources in accordance with the objectives of sustainable development' (WTO, 1999). Moreover, as often repeated by environmentalists, Article XX of GATT mentions a number of exceptions to the principle of trade liberalisation, including that 'nothing in this Agreement shall be construed to prevent the adoption or enforcement by any contracting party of measures... (b) necessary to protect human, animal or plant life or health... (g) relating to the conservation of exhaustible natural resources if such measures are made effective in conjunction with restrictions on domestic production or consumption' (WTO, 1999). Thus, Beukel contends that 'the basic principle of the WTO trade regime today is more heterogeneous and contentious than the notion "open markets and liberalised trade is good for global welfare," and hence, more vulnerable to divergent interpretations and country positions' (2001: 141; cf. Bronckers, 2001: 53: Shrybman, 2001: 16. Williams, 2001).

8 Note that these are all 'friendly' critics, that is, Habermasian revisionists.

\section{REFERENCES}

Arendt, H. (1958) The Human Condition, Chicago: University of Chicago Press. Barfield, C. (2001) Free Trade, Sovereignty, Democracy, Washington: AEI Press.

Bellmann, C. and Gerster, R. (1996) 'Accountability in the World Trade Organisation', Journal of World Trade, 30(6): 31-74.

Bello, W. (2000), 'Building an Iron Cage: Bretton Woods Institutions, the WTO, and the South', in S. Anderson (ed.) Views from the South, the Effects of Globalisation and the WTO on Third World Countries, Oakland: Food First Books, pp. 54-90.

Benhabib, S. (1996) 'Introduction: the Democratic Moment and the Problem of Difference'; and 'Toward a Deliberative Model of Democratic Legitimacy', in S. Benhabib (ed.) Democracy and Difference, Contesting the Boundaries of the Political, Princeton: Princeton University Press, pp. 3-18, 67-94.

Bernstein, R. (1993) The New Constellation, Cambridge: MIT Press.

Beukel, E. (2001) 'Greening the World Trade Organisation Trade Regime? Towards a Structural Power Model', Journal of International Relations and Development, $4(2): 138-56$

Blackhurst, R., Lyakurwa, B. and Oyejide, A. (2000) 'Options for Improving Africa's Participation in the WTO', World Economy, 23(4): 491-510.

Bronckers, M. (2001) 'More Power to the WTO?', Journal of International Economic Law, 4(1): 41-65.

Calhoun, C. (1992) 'Introduction: Habermas and the Public Sphere', in C. Calhoun (ed.) Habermas and the Public Sphere, Cambridge: MIT Press, pp. 1-47.

Chadha, R., Hoekman, B., Martin, W., Oyejide, A., Pangestu, M., Tussie, D. and Zarrouk, J. (2000) 'Developing Countries and the Next Round of WTO Negotiations', World Economy, 23(4): 431-6.

Clarkson, S. (1999) 'Are Canadians Impotent Before the World Trade Organisation?', The Globe and Mail, 19 July.

Conca, K. (2000) 'The WTO and the Undermining of Global Environmental Governance', Review of International Political Economy, 7(3): 484-94.

Dymond, W. and Hart, M. (2000), 'Post-modern Trade Policy, Reflections on the Challenges to Multilateral Trade Negotiations after Seattle', Journal of World Trade, 34(3): 21-38.

Esty, D. (1998) 'Why the World Trade Organisation Needs Environmental NGOs', London: International Centre for Trade and Sustainable Development. 
Esty, D. (2000) 'Environment and the Trading System: Picking up the Post-Seattle Pieces', in J.J. Schott (ed.) The WTO After Seattle, Washington: Institute for International Economics, pp. 243-52.

Fraser, N. (1989) 'What's Critical about Critical Theory? The Case of Habermas and Gender', in N. Fraser, Unruly Practices: Power, Discourse and Gender in Contemporary Social Theory, Minneapolis: University of Minnesota Press, pp. 133-43.

Fraser, N. (1992) 'Rethinking the Public Sphere: A Contribution to the Critique of Actually Existing Democracy', in Craig Calhoun (ed.) Habermas and the Public Sphere, Cambridge: MIT Press, pp. 109-42.

Gabilondo, J. (2001) 'Developing Countries in the WTO Dispute Settlement Procedures', Journal of World Trade, 35(4): 483-88.

Habermas, J. (1976) Legitimation Crisis, T. McCarthy (trans.), London: Henemann.

Habermas, J. (1989) Structural Transformation of the Public Sphere, T. Burger (trans.), Cambridge: MIT Press.

Habermas, J. (1990) Moral Consciousness and Communicative Action, C. Lenhardt and S. Weber Nicholsen (trans.), Cambridge: MIT Press.

Habermas, J. (1993a)justification and Application, Cambridge: MIT Press.

Habermas, J. (1993b) 'Further Reflections on the Public Sphere', in C. Calhoun (ed.) Habermas and the Public Sphere, Cambridge: MIT Press, pp. 421-57.

Habermas, J. (1996a) 'Three Normative Models of Democracy', in S. Benhabib (ed.) Democracy and Difference, Princeton: Princeton University Press, pp. 21-30.

Habermas, J. (1996b) Between Facts and Norms: Contributions to a Discourse Theory of Law and Democracy, W. Rehg (trans.), Cambridge: MIT Press.

Habermas, J. (1999) 'The European Nation-state and the Pressures of Globalisation' New Left Review, 235: 46-59.

Habermas, J. (2001) The Postnational Constellation, M. Pensky (ed. and trans.), Cambridge: MIT Press.

Held, D. (1995) Democracy and the Global Order, Stanford: Stanford University Press.

Keohane, R. and Nye, J. (2000) 'The Club Model of Multilateral Cooperation and the World Trade Organisation: Problems of Democratic Legitimacy', paper presented at the Conference on Efficiency, Equity, and Legitimacy: The Multilateral Trading System at the Millennium, Kennedy School of Government, Harvard University, Cambridge, MA, 1-2 June.

Khor, M. (2000) 'How the South is Getting a Raw Deal at the WTO', in S. Anderson (ed.) Views from the South, The Effects of Globalisation and the WTO on Third World Countries, Oakland: Food First Books, pp. 7-53.

Krajewski, M. (2001) 'Democratic Legitimacy and Constitutional Perspectives of WTO law', Journal of World Trade, 35(1): 167-86.

Kwa, A. (2002), 'Power Politics in the WTO: Developing Country Perspectives on Decision-making Processes in Trade Negotiations', Bangkok: Focus on the Global South.

Madeley, J. (2000), Hungry for Trade, London: Zed.

Mansbridge, J. (1996) 'Using Power/Fighting Power: The Polity', in S. Benhabib (ed.) Democracy and Difference, Princeton: Princeton University Press, pp. 4666.

McMichael, P. (2000) 'Sleepless Since Seattle: What is the WTO About?', Review of International Political Economy, 7(3): 466-74.

Moore, M. (2002) 'The WTO Door is Open, to a Point', The Globe and Mail, 12 June. Raghavan, C. (2000) 'After Seattle, World Trading System Faces Uncertain Future', Review of International Political Economy, 7(3): 495-504.

Raustiala, K. (1996), 'Democracy, Sovereignty, and the Slow Pace of International Negotiations', International Environmental Affairs, 8(1): 3-15. 
Risse, T. (2000) "'Let's Argue!": Communicative Action in World Politics', International Organisation, 54(1): 1-39.

Rugman, A. (2001) 'The World Trade Organisation and the International Political Economy', in A. Rugman and G. Boyd (eds) The World Trade Organisation in the New Global Economy, Cheltenham: Edward Elgar, pp. 1-22

Sampson, G. (2000) 'The World Trade Organisation after Seattle', World Economy. 23(9): 1097-117.

Scholte, J., O'Brien, R. and Williams, M. (1999) 'The WTO and Civil Society', Journal of World Trade, 33(1): 107-23

Schott, J.J. and Watal, J. (2000) 'Decision Making in the WTO', in J.J. Schott (ed.) The WTO After Seattle, Washington: Institute for International Economics, pp. 28392.

Shaffer, G. (2001) 'The World Trade Organisation Under Challenge', Harvard Environmental Law Review, 25(1): 1-50

Shrybman, S. (2001) The World Trade Organisation, a Citizen's Guide, Toronto: James Lorimer, 2nd edition.

Smismans, S. (2000) 'The European Economic and Social Committee: Towards Deliberative Democracy via a Functional Assembly', European Integration Online Papers, 4(12): 121, available at: http://eiop.or.at/eiop/texte/2000-012a.htm (accessed Feb. 3, 2003).

Smith, J. and Moran, T. (2000) 'WTO 101: Myths about the World Trade Organisation', Dissent, 2: 66-70.

Times of India (1999), 'WTO Sponsors Microsoft, Boeing Still Bullish', 9 December.

Steinberg, R. (2002) 'In the Shadow of Law or Power? Consensus-based bargaining in the GATTNTO', International Organisation, 56(2): 339-74.

Young, I. (1996) 'Communication and the Other: Beyond Deliberative Democracy', in S. Benhabib (ed.) Democracy and Difference, Princeton: Princeton University Press, pp. 120-35.

White, S. (1984) 'Habermas's Communicative Ethics and the Development of Moral Consciousness', Philosophy and Social Criticism, 10: 4-34.

Wilkinson, R. (2002) 'Global Monitor: the World Trade Organisation', New Political Economy, 7(1): 129-41.

Williams, M. (2001) 'In Search of Global Standards: The Political Economy of Trade and the Environment', in D. Stevis and V.J. Assetto (eds.) The international Political Economy of the Environment: Critical Perspectives, Boulder: Lynne Rienner, pp. 39-61.

World Trade Organisation (1994) 'Marrakesh Agreement Establishing the World Trade Organisation', available at: http://www.wto.org/wto/english/docs_e/ legal_e/legal_texts_e.htm\#articlesl-26 (accessed July 15, 2002).

World Trade Organisation (1996) 'Guidelines for Arrangements on Relations with NGOs', Document WT/L/162, 18 July.

World Trade Organisation (1999) Legal Texts: The Results of the Uruguay Round of Multilateral Trade Negotiations, Cambridge: Cambridge University Press.

World Trade Organisation (2000) '10 Benefits of the WTO Trading System' and '10 Common Misunderstandings about the WTO', available at: http://www.wto. org/wto/english/thewto_e/whatis_e/whatis_e.htm (accessed July 15, 2002). 